\title{
Sosyal Medya Fenomeni ve Marka İşbirliği: İşbirliği Paylaşımlarına İlişkin Instagram Kullanıcı Yorumları Üzerinden Bir Değerlendirme
}

Derya GÜL ÜNLÜ, İstanbul Üniversitesi İletişim Fakültesi Halkla İlişkiler ve Tanıtım Bölümü, Doktor Öğretim Üyesi, derya.gul@istanbul.edu.tr, 0000-0003-3936-7988

Burcu ZEYBEK, Doğuş Üniversitesi, Meslek Yüksekokulu Halkla İlişkiler ve Tanıtım Programı, Doktor Öğretim Üyesi, bzeybek@dogus.edu.tr, 0000-0002-2391-5727

$\ddot{O Z Z}$

Sosyal medya fenomenlerini, spesifik konular hakkında kişisel deneyimlerine dayalı içerik paylaşan ve bu paylaşımlar üzerinden geniş sayıda takipçi sayısına ulaşan bireyler olarak ifade etmek mümkündür. Fenomenlerin, günlük yaşam önerilerine ve deneyimlerine dayalı tavsiyelerini içeren paylaşımlarının geniş bir kullanıcı kitlesi tarafindan takip edilmesi, onlarm dijital ortamm önemli kanaat önderleri olarak kabul edilmelerini de beraberinde getirmektedir. Fenomenler tarafindan paylaşılan bu içerikler, markalar için de dikkat çekici reklam mecralarına dönüşmekte, hatta öyle ki birçok marka bir fenomen markasını da yanına alarak işbirliklerinden oluşan özel ürünler piyasaya sürmektedir. Fenomen ve marka işbirlikleriyle piyasaya sürülerek, Instagram üzerinden tanıtımı yapılan ürün paylaşımlarına odaklanan bu çalışmada, öncelikle, söz konusu işbirliği ürünlerinin sosyal medya fenomenleri tarafindan nasıl duyurulduğunun ve kullanım önerisinin nasıl gerçekleştirildiğinin ortaya koyulması amaçlanmaktadır. Sonrasinda ise, sosyal medya fenomenleri tarafindan Instagram hesaplarnda yayınlanan bu paylaşımların altına gelen kullanıcı yorumlarında öne çıkan temaların ve bu temalara ilişkin duygu durumlarmın neler olduğunun ortaya koyulması hedeflenmektedir. Bu amaç doğrultusunda, kategorisel içerik analizi tekniğiyle betimsel yönteme dayalı bir alan araştırması gerçekleştirilmiştir. Çalışma sonucunda ise, sosyal medya fenomenlerinin, Instagram hesaplarn üzerinden yayınladıkları marka işbirliği paylaşımlarında en fazla fotoğraf paylaşımında bulundukları, ürün tanıtımına odaklanan bu paylaşımları öncelikli olarak konuyla ilgili açıklama metinleri ve emojilerle destekledikleri bulgulanmıştır. Söz konusu paylaşımların altına gelen kullanıcı yorumlarının ise, sırasıyla olumlu, olumsuz ve nötr duygu durumların yansıttı̆̆ı ve kullanıciların fenomene ilişkin beğeni ya da eleştirilerinin paylaşımı yapılan işbirliği ürününe de genellenen yorumlara dönüştüğ̈̈ ortaya koyulmuştur.

Anahtar : Sosyal Medya Fenomeni, Marka işbirliği, Instagram

Kelimeler

\section{Social Media Phenomenon and Brand Collaboration: An Evaluation Of Collaborative Posts Based on Instagram User Comments}

ABSTRACT : $\quad$ Social media phenomena can be described as individuals, who share content about specific subjects based on their personal experiences and reach a large number of followers through such shared contents. The fact that posts of social media phenomena, which contain their recommendations based on daily life matters and their experiences, are followed by a vast majority of users, require them to be 


\begin{abstract}
regarded as important opinion leaders of digital media. These contents shared by social media phenomena also turn into remarkable advertising channels, such that several brands launch products, advertising of which involve collaboration with the brand of the phenomenon. The first aim of the study, which focuses on product posts shared with the collaboration of social media phenomena and brands, and advertised on Instagram, is to show how these collaboration products are announced by social media phenomena, and how recommendations to use are provided. Secondly, the study aims to show the prominent themes of user comments made to such posts shared by social media phenomena in their Instagram accounts, and emotional content of such themes. In accordance with this aim, a field research based on descriptive method was conducted with categorical content analysis. As a result of the study, it was found that social media phenomena mostly share photos in brand collaboration posts which on their Instagram accounts, and support these posts, which focus on product promotion, primarily with explanation texts and emojis. It was also shown that user comments under these posts respectively positive, negative, and neutral emotional states respectively, and the attraction and criticisms of users towards the phenomenon turn into comments, which are generalized for the collaboration product shared.
\end{abstract}

Keywords : $\quad$ Social Media Phenomenon, Brand Collaboration, Instagram

\title{
GíRiş
}

Dijital iletişim araçlarının gelişmesiyle birlikte, sıradan kullanıcılar kendi günlük hayatlarına dair içerikleri diğerleriyle paylaşabilme, paylaştıkları içeriklerle kendi yaşam stillerini bir örnekler bütünü olarak sunabilme ve böylelikle daha fazla sayıda takipçiye ulaşarak, birer sosyal medya fenomenine dönüşebilme olanağ 1 elde etmişlerdir. Günümüzde sosyal medya fenomeni olarak kabul edilen bireyler, spesifik konular hakkında kişisel deneyimlerine dayalı güncel içerikler üretmekte, takipçileriyle sürekli etkileşim halinde bulunmakta ve büyük kullanıcı kitleleri tarafından takip edilmektedirler. Bilindiği üzere, sosyal medyanın kendine özgü yapısı, onun kendi dilini ve gündemini yaratmasını sağlamıştır. Sosyal medya fenomenleri de, bu kendine özgü ortam içerisinde var olarak, günlük yaşam pratikleri ve deneyimlerine dayalı tavsiyelerini içeren paylaşımlarını, kendilerini takip eden geniş kullanıcı kitlesine aktarmaktadır. Fenomenlerin paylaştıkları içerikler üzerinden, kendilerini takip eden bu kullanıcı kitlesinin düşünceleri, kararları, davranışlarını etkileyebilme gücüne sahip olmaları, onları günümüzün yeni kanaat önderlerine dönüştürmüştür (Aslan ve Gül-Ünlü, 2016; Casalo vd., 2018; Evans vd., 2017; Li, 2013; Li \& Du, 2011; Li, 2018; Lyons \& Henderson, 2005; Sabuncuoğlu ve Göker, 2014; Watts ve Dodds, 2007; Turcotte vd., 2015; Zhao vd., 2018). Sosyal medya fenomenlerinin içerikleri aracılı̆̆ıyla kendilerini takip eden kullanıcıları yönlendirebilecek imkana sahip olması, onları markalar için de önemli reklam mecraları haline getirmektedir. Farklı alanlarda faaliyet gösteren çok sayıda marka, birer 'fenomen önerisine' dönüşerek, fenomenlerin kişisel sosyal medya hesaplarını kendi tanıtım ve reklam faaliyetleri için kullanmakta, böylelikle 
fenomenlerin takipçileri üzerindeki etkilerinden yararlanmaya çalışmaktadır (Glucksman, 2017; Sheth, 2018; Tuten ve Solomon, 2013; Özgüven ve Tayfun, 2018). Markalar için önemli bir dijital reklam mecrası haline gelen sosyal medya fenomeni hesaplarının yer aldığı dijital ortamların başında ise, Instagram gelmektedir. Instagram'da yüksek sayıda kullanıcı tarafından takip edilen ve kendisini takipçilerine bir marka olarak sunarak, onları yönlendiren fenomenlerin önerilerine dahil olmak, markaların yeni reklam ve tanıtım faaliyetleri arasında yer almaktadır (De Veirman vd., 2017; Djafarova ve Rushworth, 2017; Koronita ve Jargalsaikhan, 2016). Hatta öyle ki birçok marka kendi kişisel markasını yarattığına inandığı bir fenomeni de yanına alarak işbirliklerinden oluşan özel ürünler piyasaya sürmektedir. Söz konusu işbirliği ürünleri genellikle markanın sınırlı sayıda üretimi olmakta ve bir fenomenin seçimi doğrultusunda piyasaya sürülmekte, kullanıcının ise bu seçime güvenerek ürünü satın alması beklenmektedir. Dolayısıyla ürün bir marka çatısı altında piyasaya sürülmekle birlikte, bir fenomen markasını da taşımaktadır. Fenomen ve marka işbirlikleriyle piyasaya sürülerek, Instagram üzerinden tanıtımı yapılan ürün paylaşımlarına odaklanan bu çalışmada, öncelikle, söz konusu işbirliği ürünlerinin sosyal medya fenomenleri tarafından nasıl duyurulduğunun ve kullanım önerisinin nasıl gerçekleştirildiğinin ortaya koyulması amaçlanmaktadır. Sonrasında ise, sosyal medya fenomenleri tarafından Instagram hesaplarında yayınlanan bu paylaşımların altına gelen kullanıcı yorumlarında öne çıkan temaların ve bu temalara ilişkin duygu durumlarının neler olduğunun ortaya koyulması hedeflenmektedir. Bu amaç doğrultusunda çalışma içerisinde ilk olarak, bir kişisel markalama süreci olarak sosyal medya fenomenliği kavramına değinilerek, fenomen önerisi ve marka ilişkisi çerçevesinde fenomen ve marka işbirliklerinin marka imajına nasıl bir katkısı olabileceği ele alınacaktır. Çalışmanın araştırma bölümünde ise, fenomenlerin işbirliği paylaşımlarını nasıl duyurdukları, kullanım önerisini nasıl gerçekleştirildikleri belirlenerek, bu paylaşımlar hakkındaki kullanıcı yorumlarında öne çıkan temalara ilişkin bulgular aktarılacaktır.

\section{Kişisel Bir Marka Olarak: Sosyal Medya Fenomeni}

Dijital iletişim araçlarının gelişimi ve yaygınlaşmasıyla birlikte ortaya çıkan, bireyin kendi tanıtmak için yararlanabileceği çok sayıdaki platform, sıradan insanlar için de ulaşılabilir olmuştur (Bennet ve Holmes, 2010, s.76). Siradan bireylerin kendini diğerlerine tanıtma imkânını elde etmesi, film yıldızları, müzisyenler, sporcular, televizyon kişilikleri gibi geleneksel medya mecraları aracılığılyla tanınan ünlülere, dijital ortamda tanınan blog yazarları, vloggerlar, sosyal medya fenomenlerini de eklemiştir. Bu mikro-ünlüler, ünlüler kadar geniş olmasa da, sosyal ağlar üzerinden belirli bir takipçi kitlesi tarafından takip edilmekte ve ürettikleri içerikler üzerinden kitleleriyle sürekli etkileşim halinde bulunmaktadırlar. Mikro-ünlüleri diğer kullanıcılardan farklılaştıran en önemli unsur ise, söz konusu yeni ünlülerin 
paylaşımları üzerinden kendi günlük pratiklerini, tercihlerini diğerlerine bir marka olarak sunmaları yani kendi kişisel markalarını yaratmalarıdır. Bu çerçevede Labrecque ve arkadaşları (2011, s.38), teknolojik bariyerlerin ortadan kalkması ve aynı anda birçok yerde olabilme imkânı sunması bakımından internetin kişisel markalama için mükemmel bir ortam olduğunu vurgulamakta, Khamis ve arkadaşları (2017, s.196), kişisel markalamayla birlikte sıradan kullanıcıların da çevrimiçi üne ulaşabileceklerinin altını çizmektedir. Özellikle Instagram gibi, diğer sosyal ağlara nazaran, daha görsele dayalı platformların ise, görsel paylaşım imkanı ve popülerliği dolayısıyla kişisel markalama sürecinde kullanıcısına daha yaratıcı araçlar sunduğundan bahsedilmektedir (Casalo, 2018, s.2). Üstelik söz konusu araçlarla (anlık hikâye paylaşma, web sayfalarına link verme, çeşitli görsel efektlerden yararlanma, etiket kullanma gibi), kişisel markalama çok daha kisa bir süre içerisinde gerçekleştirilebilmektedir. Bu çerçevede fenomenlerin kısa bir süreçte itibar, stil, tutum ve beceriler aracılığı ile kişisel markalama yaptıkları söylenebilir. Dolayısıyla fenomenlerin sosyal ağlar üzerinden yaptıklarının öncelikle dijital ortamda kendilerini markalamak ve sonrasında ise elde ettikleri popülerite aracılığ ile takipçileri üzerinde çoğu zaman birer kanaat önderi olmak biçiminde tarif edilmesi mümkündür (Aslan ve Gül-Ünlü, 2016, s.53).

Sosyal medya fenomenlerini, en genel anlamıla, spesifik konular hakkında kişisel deneyimlerine dayalı içerikler üreten, takipçileriyle sürekli etkileşim halinde bulunan ve bu ürettikleri içerikler üzerinden geniş takipçi sayısına ulaşan bireyler olarak tanımlamak mümkündür. Fenomenler, geleneksel ünlülerden farklı olarak, takipçilerini tanımakta, onlara cevap vermekte, popülerliklerini arttırmak için takipçileriyle etkileşimlerini sürdürme zorunluluğu hissetmekte ve alışılmış izleyicisanatçı ya da seyirci-gösteri ikiliğini de kırmaktadırlar* (Marwick, 2016, s.345). Bu bakımdan geleneksel ünlülerden farklı olarak, sosyal medya fenomenleri hem mesaj içeriğini bağımsız bir biçimde (herhangi bir editöryal süreçten geçmeden ya da program formatına uygun olarak yapılandırılmadan) belirlemekte (Khamis vd., 2017, s. 198) hem daha etkileyici olabilmek amacıyla çeşitli sosyal medya topluluklarında yer alarak, yüksek kaliteliği içeriği düzenli ve sistematik bir biçimde sunmakta (Tuten ve Salomon, 2013, s.14), hem de takipçileriyle kurduğu iletişim ve etkileşimi stratejik olarak sürdürmektedir (Marwick, 2010, s.121). Fenomen ve takipçi etkileşiminin sürekliliği ise, fenomenin popülerliğinin devamlılı̆̆ı için gerekli

\footnotetext{
* Söz konusu izleyici-sanatçı ikililiğinin kırılması ve sıradan bireyin kendi kişisel markasını yaratarak bir fenomene dönüşmesi sürecinde izleyicinin yani sosyal medya kullanıcısının da aktif bir rol aldığını eklemek gerekmektedir. Sosyal medya kullanıcıları, kendi tercihleri ve ilgi alanları doğrultusunda fenomenleri seçmekte, takip etmekte ve onların önerilerini dikkate almaktadırlar. Bu bağlamda, Gamson (2011: 1066) sosyal medyanın, kullanıcısına tercih ettiğini 'star yapabilme gücü' verdiğinden bahsetmekte ve fenomenlerin kullanıcıların bu gücünden yararlandığının altını çizmektedir.
} 
olduğundan, geleneksel medyada yer alan yıldızlar ve fanları arasındaki ilişkiye nazaran daha gerçek görülmektedir (Senft, 2008, s.28).

Fenomenler belli bir kitlenin sürekli izlediği, o kitle için fikir lideri olarak kabul edilen kişilerdir. Bu nedenle fenomenin yaptığı her şey ünlülere kıyasla çok daha dikkat çekici ve ilgi uyandırıcı olabilmektedir (Balık, 2017). Bu çerçevede ünlülerin seçimleri ya da önerilerine ortak bir referans grubu olarak başvurulduğu düşünüldüğünde (Djafarova ve Rushworth, 2017, s.2), ünlülerin düşünceleri, tercihleri ya da önerileri, onları takip eden diğerleri açısından oldukça önem kazanmaktadır. Dolayısıyla, tıpkı ünlüler gibi, fenomenlerin de takipçileriyle paylaştıkları beğeni ya da tavsiyelerin onları takip eden diğerlerinin fikir ve kararları üzerinde belirleyici olacağını söylemek mümkündür. Bu çerçevede gerçekleştirilen çalışmaların, fenomenin takipçi sayısı ile kanaat önderliği arasında olumlu bir ilişki bulunduğunu (Yoganarasimhan 2012; Feng 2016; Hwang 2015), fenomenin takipçi sayısının yüksekliğinin onun popülerliğinin bir göstergesi olduğunu (Cha vd., 2010; De Veirman vd., 2017; Romeo vd., 2011) ortaya koyduğu görülmektedir.

\section{Fenomen Önerisi ve Marka İlişkisi}

Sosyal medya fenomenleri, markalara, takipçileri aracılığıyla oldukça geniş bir sosyal ağ inşa etme imkânı sunmaktadır. Markaların, fenomen hesapları içerisindeki hikâyeleştirilmiş postlarda yer alarak, fenomenin takipçi kitlesinden ve takipçileriyle kurduğu etkileşimden yararlanmayı hedeflemesi ise, dijital bir ağızdan ağza iletişime olanak sağlamaktadır. Söz konusu dijital ağızdan ağza iletişim aracılığıyla, kullanıcılar arasında hedeflenen sosyal etkileşim kurulabilmekte ve markaya dair bilgiler kullanıcılar arasında yaygınlaştırılabilmektedir (Abidin, 2016; Boyd \& Ellison, 2007; De Veirman vd., 2017; Jansen vd., 2009; Knoll, 2016; Lyons \& Henderson, 2005). Bu çerçevede Instagram ise, kullanıcılar tarafından mobil telefonlar aracılığıyla kolaylıkla ulaşılabildiğinden dijital ağızdan ağıza iletişim sürecinde ikna edici ve etkileme gücüne sahip bir bilgi kaynağı olarak diğer sosyal ağlar arasında ön plana çıkmaktadır (Thoumrungroje, 2014). Instagram'da fenomenler aracılığıyla başlatılan dijital ağızdan ağza iletişim sürecinin marka tanıtımında önemli bir unsur olarak ortaya çıkmasının bir nedeni de fenomenlerin, geleneksel medya ünlülerine nazaran, daha güvenilir bulunmasıdır (De Veirman vd., 2017; Djafarova ve Rushworth, 2017; Kotonita ve Jargalsaikhan, 2016). Konuyla ilgili olarak, De Veirman ve arkadaşları (2017, s. 798) fenomenlerin takipçileri tarafından 'güvenilir bir trend öncüsü' olarak görüldüğünün altını çizmektedir. Dolayısıyla fenomenlerin takipçileriyle kurdukları bu yakınlık ve güven ilişkisi markaların kazanç elde etmek istedikleri önemli kanallara dönüşmektedir (Hearn ve Schoenhoff, 2016; Gormley, 2016). Bu bakımdan dijital reklam stratejilerine odaklanan markalar için fenomen hesapları marka ve ürün tanıtımlarında oldukça önemli bir hal almaktadır. Ayrıca takipçilerin fenomene olan güven ve sempatileri verilen reklam 
mesajına direnci de azaltmakta, fenomenlerden yararlanılarak gerçekleştirilen reklam faaliyetleri, geleneksel reklama nazaran, daha etkili görülmektedir (de Vries vd., 2012; Kotonita ve Jargalsaikham, 2016).

Fenomen önerisine olan ilginin artmasının nedenlerinden biri de reklam mesajının hedef kitleye ulaştırılmasının gittikçe zorlaşmasıdır. Çünkü günümüzde bireyler, tıpkı kendilerine geleneksel kanallardan ulaşan reklam mesajlarını atlayabilecekleri gibi, dijital kanallardan ulaşan reklam mesajlarını da okumayabilmekte ya da çeşitli yazılımlar aracılığıyla engelleyebilmektedir. Fenomenlerin önerileri doğrultusunda takipçilere ulaşmak, hem geleneksel ve dijital reklam kanalları aracılığıyla hedef kitleye ulaşılamama sorununu ve hedef kitlenin reklam mesajından kaçınması ya da mesaja direnmesi ihtimalini azaltmakta (Fransen vd., 2015; Kaikati ve Kaikati, 2004) hem de fenomenin takipçileri üzerindeki olumlu imajından faydalanılmasını sağlamaktadır. Ayrıca fenomen önerileri, fenomenin kişisel yaşamına ilişkin yazılı ve görsel ifadelerini içeren paylaşımlarla birlikte gerçekleştirilmekte ve kişisel bir niteliği bulunmaktadır. Bu bakımdan kullanıcılar tarafından, fenomen önerilerinin, fenomenin önyargısız fikirlerini içerdiği düşünülmekte ve ikna edici bir gücü olduğu varsayılmaktadır (Abidin, 2015). Dolayısıyla reklamverenler, belirli bir mesajı ya da yeni bir ürüne ilişkin bilgiyi fenomenler aracılığıyla onların sosyal ağları üzerinden yayarak, yüksek düzeyde etki elde etmeyi amaçlamaktadır (Keller ve Berry, 2003; Weimann, 1994).

Buna ek olarak, fenomenler tarafından yayılan tanıtım mesajı ya da ürüne ilişkin bilgi, sadece fenomenin takipçileriyle sınırlı kalmamakta, takipçilerin ilişki içerisinde olduğu diğer kullanıcılara da ulaştırılabilmekte (kullanıcıların fenomen paylaşımlarını re-post etmeleri ya da kullanıcı yorumlarındaki etkileşimler aracılığıyla), böylelikle fenomenler tarafından paylaşılan gönderiler çok daha geniş bir kullanıcı kitlesine aktarılmakta ve hem fenomenin hem de içeriğin görünürlüğü artmaktadir (Scott, 2011; Thomas, 2004; Woods, 2016). Bu çerçevede değerlendirildiğinde, aslında kullanıcının da değer yaratma sürecine aktif olarak katıldığını, fenomen önerilerini kendi hesapları üzerinden diğer kullanıcılarla paylaşarak, fenomenin paylaşımının etkisini arttırdığını ve bunun da markaya katkı sağladığını söylemek mümkündür (Vargo ve Lusch, 2008). Yani, Auh'un (2007) da vurguladığı gibi, sadece fenomen kullanıcılar için değer üretmemekte, kullanıcılar da fenomen için değer üretmektedir. Bu bakımdan fenomen önerisinde yer alan markanın değerine kullanıcıların da katkı sağlayabileceği ifade edilebilir. Fenomen önerisine kullanıcı katkısının sağlanması, öneride yer alan ürün ya da hizmetin kullanıcının ilgi alanında yer almasını gerekli kılmaktadır. Bu nedenle, fenomen önerisi etkisinin, kullanıcının ilgi alanıyla uyuştuğu durumlarda çok daha etkili olduğunu söylemek mümkündür (Choi ve Rifon, 2012).

\section{Fenomen Önerisi ve Marka İmajı}


Marka imajı, en genel anlamıyla, "hedef kitlenin marka hakkındaki algılarını, dolaylı veya dolaysiz tecrübelerini" ifade etmektedir (Perry ve Wisnom III, 2004, ss.15-16). Daha detaylı bir tanımda ise, marka imajının "tüketicilerin marka ile olan deneyimlerinden, duyduklarından, reklamlarından, paketlemesinden, hizmetlerinden vb. elde edindiği bilgi toplamının, seçici algı, önceki inanışları, toplumsal normları tarafından değişikliğe uğramış hali" olarak tanımlandığı görülmektedir (Randall, 2005, s.18). Dolayısıyla, marka imajının, "markanın hedef kitle tarafından nasıl algılandiğının bir göstergesi" olduğunu söylemek mümkündür (Aaker, 2014, s.71). Bu çerçevede değerlendirildiğinde, hedef kitle nezdinde olumlu bir imaja sahip olmak isteyen reklamverenler için, güvenilir bir sosyal medya fenomeni önerisi içerisinde hedef kitleye sunulmanın da oldukça önemli bir hal aldığını ifade etmek yanlış olmayacaktır. Çünkü, sosyal medyanın bir pazarlama aracı olarak kullanımı, marka ve hedef kitle etkileşimini desteklemekte ve iki taraf arasındaki ilişkinin güçlenmesiyle birlikte hedef kitlenin zihnindeki markanın konumunu da kuvvetlendirerek, marka değerine katkıda bulunmaktadır. $\mathrm{Bu}$ nedenle güvenilir bir fenomen önermesine dönüşmenin, önerilen markanın da güvenilirliğini etkileyerek (Elberse ve Verleun, 2012; Nicolau ve Santa-Maria, 2013; Spry vd., 2011), marka imajına olumlu bir değer kattığını söylemek mümkündür (McCracken, 1989; Ohanian, 1990). Bu çerçevede değerlendirildiğinde, "sosyal medyada bir marka mesajının, hedef kitlesine ulaştırılması görevini üstlenen" (Lim vd., 2017, s.20), fenomenlerle gerçekleştirilen marka işbirliklerinin olumlu bir marka imajı yaratılması sürecindeki işlevlerini şöyle sıralamak olanaklıdır (Çarkacı, 2018):

- Takipçiler, fenomen kampanyalarını, diğer mecralardaki içeriklere nazaran, çok daha yüksek oranda arkadaşlarıyla paylaşmaktadırlar.

- Sosyal medya fenomenleri, markayla birlikte gerçekleştirdikleri işbirliği paylaşımları dışında da takipçilerine ürünle ilgili bilgiler aktarabilmektedir.

- Kampanya süresi ve sonrasında, birçok takipçi hem paylaşılan içeriğe yorum yaparak hem de özel mesaj aracılığıyla fenomene ulaşarak, marka ile ilgili görüşlerini ya da sorularını iletebilmektedir.

- Sosyal medya fenomenleri, kampanya süresince aslında kendi markalarını tanıttıklarından işbirliği yaptıkları markanın gönüllü elçilerine dönüşmektedir.

- Takipçiler, fenomen önerisine yorum yapan diğerlerini tanımasalar da, ürüne ilişkin yorumlar diğer okuyucuların fikirleri üzerinde belirleyici olmaktadır.

- Fenomenlerle yapılan işbirlikleri markaların çekim, montaj, kayıt, içerik, reklam metni, prodüksiyon, yönetmen ya da oyuncu gibi ekstra maliyetlerini azaltmaktadir.

- Sosyal medya fenomenleriyle gerçekleştirilen marka işbirlikleri, farklı sektörlerde bulunan çok sayıda marka için, diğer birçok geleneksel mecraya nazaran, daha düşük bir bütçeyle geniş bir hedef kitleye ulaşım imkanı sunmaktadir. 
Dolayısıyla, markaların kendi ürün ya da hizmetlerinin önerisini yapmaları için seçtikleri sosyal medya fenomenini hedefledikleri markanın imajına katkı yapacak içeriği üreten bireyler arasından tercih etmeleri de oldukça önem taşımaktadır. Çünkü fenomen önerisi, aslında fenomenin kendi imajını söz konusu markaya transfer etmesi anlamına gelmektedir. Konuyla ilgili olarak, Araujo ve arkadaşları (2017), bu süreçte dikkat edilmesi gereken en önemli unsurun, uygun fenomenin ya da kanat önderinin seçimi olduğunu vurgulamaktadır. Ürün ya da marka önerisinde bulunacak uygun fenomenin seçiminde ise, göz önünde bulundurulması gereken bazı kriterlerle karşılaşılmaktadır. Örneğin; Zhang ve Dong (2008), dijital kanaat önderinin seçiminde takipçi sayısının önemi kadar, takipçilerin aktif sosyal medya kullanıcıları olup olmadıklarına da dikkat edilmesi gerektiğini belirtmektedir. Casalo ve arkadaşları (2018) ise, kanaat önderlerine dönüşen fenomenlerin yayınladıkları içeriklerin orijinal olmasının ve söz konusu içeriğin hem var olan hem de potansiyel takipçiler tarafından eşsiz olarak algılanmasının önem taşıdığından bahsetmektedir. Bunlara ek olarak, De Veirman ve arkadaşları (2017), takipçilerine günlük yaşam pratikleri üzerinden bir yaşam stili sunan fenomenin imajıyla, markanın kendisine ilişkin sahip olmak istediği imajın birbirine uyumlu olması gerektiğinin altını çizmektedirler. Ayrıca fenomenin takip ettiği hesap sayısının da kullanıcı algısı üzerinde belirleyici olduğundan bahsetmekte ve fenomenin az sayıda hesap takip etmesinin kullanıcılar nezdinde negatif bir algıya neden olacağını eklemektedirler (2017, s.798). Son olarak, Evans ve arkadaşları (2017) ise, markalar tarafından seçilecek fenomenin kullanıcı kitlesiyle markanın hedef kitlesinin benzer özelliklere sahip olması gerektiğini belirtmekte, aksi durumda hem öneride bulunan fenomene hem de önerilen ürüne yönelik negatif bir algı oluşacağını vurgulamaktadırlar.

\section{Araştırmanın Amacı}

Araştırma, sosyal medya fenomenleri ve kozmetik-kişisel bakım alanında faaliyet gösteren markalar arasında gerçekleştirilen işbirlikleri aracılığıyla piyasaya sürülen ve Instagram üzerinden tanıtımı yapılan ürünlerin, sosyal medya fenomenleri tarafından duyurusunun ve kullanım önerisinin nasıl gerçekleştirildiğinin belirlenmesi amacını taşımaktadır. Ayrıca sosyal medya fenomenleri tarafından Instagram hesaplarında yayınlanan bu paylaşımların altına gelen kullanıcı yorumlarında öne çıkan temaların ve bu temalara ilişkin duygu durumlarının neler olduğunun ortaya koyulması da hedeflenmektedir. $\mathrm{Bu}$ çerçevede çalışma kapsamında yanıt aranan amaç sorularını şöyle sıralamak mümkündür:

AS1: Sosyal medya fenomenlerinin Instagram hesaplarının genel özellikleri (takipçi sayısı, takip edilen kişi sayısı, paylaşılan içerik sayısı, günlük ortalama takipçi artışı, haftalık ortalama takipçi artışı, aylık ortalama takipçi artışı, ortalama etkileşim oranı) nelerdir? 
AS2: Sosyal medya fenomenlerinin gerçekleştirdikleri marka işbirliklerine dair Instagram hesaplarındaki paylaşım oranları nelerdir?

AS3: Sosyal medya fenomenleri, Instagram hesapları üzerinden yayınladıkları marka işbirliği paylaşımlarında hangi paylaşım türünü/türlerini (fotoğraf/hareketli fotoğraf/video/sesli video) öncelikli olarak tercih etmektedirler?

AS4: Sosyal medya fenomenleri, Instagram hesapları üzerinden yayınladıkları marka işbirliği paylaşımlarında hangi içerik özelliğini/özelliklerini (etiketleme/hashtag kullanma/metin kullanma/emoji kullanma/mention kullanma/link ekleme/konum bilgisi ekleme) kullanmayı öncelikli olarak tercih etmektedirler?

AS5: Sosyal medya fenomenleri, Instagram hesapları üzerinden yayınladıkları marka işbirliği paylaşımlarında hangi paylaşım içeriğini/içeriklerini (bilgilendirme/tanıtma/etkinlik duyurma/satış çağrısı) kullanmayı öncelikli olarak tercih etmektedirler?

AS6: Sosyal medya fenomenlerinin Instagram hesapları üzerinden yayınladıkları marka işbirliği paylaşımlarının altına gelen takipçi yorumlarında ön plana çıkan temalar (fenomen, ürün ya da paylaşım beğenisi/ fenomen, ürün ya da paylaşım eleştirisi/fiyat, ürün ya da paylaşım bilgisi) nelerdir? Bu temalara ilişkin duygu durumları nasildır?

\section{Araştırmanın Yöntemi}

Çalışma, kategorisel içerik analizi tekniğiyle gerçekleştirilen betimsel yönteme dayalı bir alan araştırması niteliği taşımaktadır. Kategorisel içerik analizi, belirli bir mesajın önce kategorilere bölünmesini ve ardından bu birimlerin, belirli kriterlere göre kategoriler halinde gruplandırılmasını ifade etmektedir. Kategorilendirme ise, mesajların kodlanmasını, yani anlamlarının işlenmesini gerektirmektedir (Bilgin, 2006, s.19). Bu çerçevede gerçekleştirilen araştırma, sosyal medya fenomenlerinin Instagram hesaplarındaki işbirliği paylaşımlarının temel özelliklerine ve kullanıcı yorumlarına ilişkin kategorilerin kodlanmasını içerdiğinden, kategorisel içerik analizi tekniğinden yararlanılması uygun görülmüştür. Betimsel verilerden yola çıkılarak sayısal çözümlemelere ulaşma amacı taşıyan bu çalışmada, araştırma evrenini, sosyal medya fenomenleri ve markalar tarafından gerçekleştirilen işbirlikleri aracılığıyla piyasaya sürülen ve fenomenlerin hesapları üzerinden duyurusunun ve tanıtımının yapıldı̆̆ı Instagram paylaşımları oluşturmaktadır. Çalışmanın örneklemi ise, yüksek oranda kullanıcı tarafından takip edilen fenomenlerin yer aldığı, kozmetik-kişisel bakım alanında içerik üreten ve yine bu alanda faaliyet gösteren markalarla işbirliği gerçekleştirerek, bunları Instagram 
hesabından kullanıcı yorumlarına açık bir biçimde yayınlayan, en yüksek takipçi sayısına sahip ilk üç fenomenin işbirliği paylaşımları olarak belirlenmiştir. Söz konusu sosyal medya fenomenlerini ve takipçi sayılarını şöyle sıralamak mümkündür: (1) Duygu Özaslan (@duyguozaslan); 1.737.381, (2) Merve Özkaynak (@mevy); 863.677, (3) Sebile Ölmez (@sebibebi); 459.677*.

Kategorisel analiz, 6 ana kategorinin oluşturulması ve bu ana kategorilere bağlı olarak belirlenen alt kategorilerin söz konusu paylaşımda bulunması ya da bulunmamasına bağlı olarak gerçekleştirilen kodlama sürecini içermektedir. Buna göre, belirlenen 6 ana kategoriyi şöyle sıralamak mümkündür: (1) sosyal medya fenomenlerinin Instagram hesaplarının genel özellikleri, (2) sosyal medya fenomenlerinin gerçekleştirdikleri marka işbirliklerine dair Instagram hesaplarındaki paylaşım oranları, (3) sosyal medya fenomenlerinin Instagram hesapları üzerinden yayınladıkları marka işbirliği paylaşımlarında öncelikli olarak tercih ettikleri paylaşım türü/türleri, (4) sosyal medya fenomenlerinin Instagram hesapları üzerinden yayınladıkları marka işbirliği paylaşımlarında öncelikli olarak tercih ettikleri içerik özelliği/özellikleri, (5) sosyal medya fenomenlerinin Instagram hesapları üzerinden yayınladıkları marka işbirliği paylaşımlarında öncelikli olarak tercih ettikleri paylaşım içeriği/içerikleri, (6) sosyal medya fenomenlerinin Instagram hesapları üzerinden yayınladıkları marka işbirliği paylaşımlarının altına gelen takipçi yorumlarında ön plana çıkan temalar ve bu temalara ilişkin duygu durumları.

Söz konusu 6 ana kategori kapsamında belirlenen alt kategorileri ise, şöyle sıralamak olanaklıdır: Birinci kategori için, (a) takipçi sayısı, (b) takip edilen kişi sayısı, (c) paylaşılan içerik sayısı, (d) günlük ortalama takipçi artışı, (e) haftalık ortalama takipçi artışı, (f) aylık ortalama takipçi artışı; (g) ortalama etkileşim oranı; ikinci kategori için, (a) işbirliği paylaşım sayısı; üçüncü kategori için, (a) fotoğraf, (b) hareketli fotoğraf, (c) video (arka planda sadece müziğin bulunduğu), (d) sesli video (arka planda hem müziğin hem de fenomen konuşmalarının bulunduğu), beşinci kategori için, dördüncü kategori için, (a) etiketleme, (b) hashtag kullanma, (c) metin kullanma, (d) emoji kullanma, (e) mention kullanma, (f) link ekleme, (g) konum bilgisi ekleme; beşinci kategori için, (a) bilgilendirme, (b) tanıtma, (c) etkinlik duyurma, (d) satış çağrısı; altıncı kategori için; (a) olumlu yorumlar; (1) fenomen beğenisi, (2) ürün beğenisi, (3) paylaşım beğenisi, (b) olumsuz yorumlar; (1) fenomen eleştirisi, (2) ürün eleştirisi, (3) paylaşım eleştirisi, (c) nötr yorumlar; (1) fiyat bilgisi, (2) ürün bilgisi, (3) paylaşım bilgisi. Buna ek olarak, kullanıcı yorumlarının analiz edildiği altıncı kategori kapsamında, sosyal medya fenomenlerinin en çok yoruma sahip ilk üç marka işbirliği paylaşımının altına gelen yorumlar analiz edilmiş ve analiz sürecinde karşılaşılan reklam içerikli ya da paylaşılan marka işbirliğiyle ilgisi

\footnotetext{
* Söz konusu verilere, 24.04 .2020 tarihinde erişilmiştir.
} 
olmayan kullanıcı yorumları kapsam dışında bırakılmıştır. Dolayısıyla, içeriklerine bağlı olarak çalışmaya dahil edilmesi uygun görülen 2.262 kullanıcı yorumu (Duygu Özaslan için; 369, Merve Özkaynak için; 1.009, Sebile Ölmez için; 884) belirlenen araştırma kriterleri doğrultusunda kodlanırken, 185 kullanıcı yorumu (Duygu Özaslan için; 156, Merve Özkaynak için; 26, Sebile Ölmez için; 3) kodlama sürecine dahil edilmemiştir. Kodlama sürecinde çalışmanın araştırmacıları olan 2 kodlayıcıdan yararlanılmış, ancak kodlamaların güvenilirliğinin sağlanabilmesi için, kodlayıcılar tarafından gerçekleştirilen kodlama işlemi, tamamlandıktan bir süre sonra tekrar edilerek, her iki kodlayıcı arasındaki uygunluk kontrol edilmiştir. Çalışmanın geçerliliğinin sağlanabilmesi için ise, analiz sürecinde kullanılan ana kategori ve alt kategoriler önceden tanımlanmıştır. Ancak 6. ana kategori için kullanıcı yorumlarının içeriğinin önceden tanımlanabilmesinin zorluğundan kaynaklanan kodlama farklılıklarının engellenebilmesi amacıyla, kodlama sürecini gerçekleştiren ilk kodlayıcı tarafından yorumların hangi kategorilere dahil edildiğine dair bir kodlama formu (Bknz. Ek 1) oluşturulmuştur. Söz konusu kodlama formu, sonrasında, ikinci kodlayıcı tarafından gerçekleştirilen kodlama sürecinde de bir kılavuz olarak kullanılmıştır. Böylelikle, kullanıcı yorumlarına dair ilişkili kategorilerin tanımlanmasında kodlayıcılar arasında üst düzey bir anlaşmanın sağlanması hedeflenmiştir. Tüm kategorilerin kodlama süreci, 24.04.2020-20.05.2020 tarihleri arasında tamamlanmıştır. Tamamlanan kodlamaların içerik sayısı (n) ve yüzdesine, kategorisel içerik analizi tablolarında karşılaştırmalı olarak yer verilmiştir.

\section{Bulgular}

Çalışmanın araştırma sorularına uygun olarak, aşağıda gerçekleştirilen kategorisel içerik analizi çerçevesinde elde edilen araştırma bulguları aktarılmaktadır.

Tablo 1. Fenomenlerin Instagram hesaplarının genel özellikleri

\begin{tabular}{|l|c|c|c|}
\cline { 2 - 4 } \multicolumn{1}{c|}{} & Duygu Özaslan & Merve Özkaynak & Sebile Ölmez \\
\hline Takipçi Sayısı & 1.737 .381 & 863.677 & 459.677 \\
\hline Takip Edilen Kişi sayısı & 800 & 664 & 1.132 \\
\hline Paylaşılan İçerik Sayısı & 3.367 & 2.724 & 2.519 \\
\hline Günlük Ortalama Takipçi Artışı & 2.896 & 225 & 224 \\
\hline Haftalık Ortalama Takipçi Artışı & 31.616 & 737 & 1.789 \\
\hline Aylık Ortalama Takipçi Artışı & 223.768 & 5.983 & 12.805 \\
\hline Ortalama Etkileşim Oranı & $\% 11.91$ & $\% 3.31$ & $\% 1.65$ \\
\hline
\end{tabular}

Yukarıdaki tabloya göre, en fazla takipçi sayısı bulunan Instagram hesabı Duygu Özaslan'a aittir ve onu sırasıyla Merve Özkaynak ve Sebile Ölmez'in hesapları takip etmektedir. Instagram hesabı üzerinden en fazla kişiyi takip eden sosyal medya 
fenomenin ise, Sebile Ölmez olduğu, sonrasında Duygu Özaslan ve Merve Özkaynak'ın geldiği görülmektedir. Ayrıca söz konusu hesaplar üzerinden şimdiye dek paylaşılmış içerik sayısına bakıldığında, en yoğun içeriğin Duygu Özaslan tarafından paylaşıldığını, onu sorasıyla Merve Özkaynak ve Sebile Ölmez'in hesaplarının takip ettiğini söylemek mümkündür. Bununla birlikte, yine Duygu Özaslan'ının Instagram hesabının ortalama takipçi sayısı artışının en yüksek düzeyde olduğu, sonrasında Sebile Ölmez'in Instagram hesabının geldiği, en düşük düzeyde ortalama takipçi sayısı artışına sahip olan Instagram hesabının ise, Merve Özkaynak'a ait olduğu belirtmek olanaklıdır. Instagram hesaplarının ortalama etkileşim oranları incelendiğinde ise, en yüksek etkileşime sahip hesabın \%11.91 ile Duygu Özaslan'a ait olduğu, sonrasında \%3.31 ile Merve Özkaynak ve \%1.65 ile Sebile Ölmez'in geldiği görülmektedir.

Tablo 2. Fenomenlerin marka işbirliklerine ilişkin paylaşım sayısı

\begin{tabular}{|l|c|c|}
\cline { 2 - 3 } \multicolumn{1}{c|}{} & $\mathbf{n}$ & $\mathbf{\%}$ \\
\hline Duygu Özaslan & 12 & $\% 25$ \\
\hline Merve Özkaynak & 18 & $\% 38$ \\
\hline Sebile Ölmez & 18 & $\% 38$ \\
\hline Toplam & $\mathbf{4 8}$ & $\mathbf{\% 1 0 0}$ \\
\hline
\end{tabular}

Tabloya göre, en fazla marka işbirliği paylaşımı gerçekleştirmiş olan sosyal medya fenomeninin Sebile Ölmez olduğu görülmektedir. Sebile Ölmez'den daha az olan Merve Özkaynak ve Duygu Özaslan'ın paylaşımları ise, aynı orandadır.

Tablo 3. Fenomenlerin marka işbirliği paylaşımlarında tercih ettikleri paylaşım türleri

\begin{tabular}{|l|c|c|c|c|c|c|c|c|}
\cline { 2 - 10 } \multicolumn{1}{c|}{} & \multicolumn{2}{c|}{ Duygu Özaslan } & \multicolumn{2}{c|}{ Merve Özkaynak } & \multicolumn{2}{c|}{ Sebile Ölmez } & \multicolumn{2}{c|}{ Toplam } \\
\cline { 2 - 10 } \multicolumn{1}{c|}{} & $\mathbf{n}$ & $\mathbf{\%}$ & $\mathbf{n}$ & $\mathbf{\%}$ & $\mathbf{n}$ & $\mathbf{\%}$ & $\mathbf{n}$ & $\mathbf{\% 1 0 0}$ \\
\hline Fotoğraf & 9 & $\% 24,3$ & 17 & $\% 45,9$ & 11 & $\% 29,7$ & $\mathbf{3 7}$ & $\mathbf{\% 1 0 0}$ \\
\hline Hareketli Fotoğraf & - & - & - & - & - & - & - & - \\
\hline Video & 3 & $\% 33,3$ & 1 & $\% 11,1$ & 5 & $\% 55,5$ & $\mathbf{9}$ & $\mathbf{\% 1 0 0}$ \\
\hline Sesli Video & - & - & - & - & 2 & $\% 100$ & $\mathbf{2}$ & $\mathbf{\% 1 0 0}$ \\
\hline
\end{tabular}

Yukarıda yer verilen tabloya göre, sosyal medya fenomenleri, Instagram hesapları üzerinden yayınladıkları marka işbirliği paylaşımlarında en fazla fotoğraf paylaşımında bulunmakta, bunu video ve sesli video paylaşımları takip etmektedir. Marka işbirliği duyuruları için fotoğraf paylaşımında bulunan Instagram fenomenlerinin paylaşım yoğunlukları sırasıyla şöyledir: Merve Özkaynak, Sebile Ölmez, Duygu Özaslan. Marka işbirliği duyuruları için video paylaşımında bulunan 
Instagram fenomenlerinin paylaşım yoğunluklarını ise şöyle sıralamak mümkündür: Sebile Ölmez, Merve Özkaynak, Duygu Özaslan. Bununla birlikte, marka işbirliği paylaşımları çerçevesinde Instagram hesabı üzerinden sadece Sebile Ölmez'in arka planda hem müziğin hem de fenomen konuşmalarının bulunduğu sesli video paylaşımında bulunduğu görülmektedir. Instagram hesabı üzerinden hareketli fotoğraf paylaşan sosyal medya fenomeni ise, bulunmamaktadır.

Tablo 4. Fenomenlerin marka işbirliği paylaşımlarında tercih ettikleri içerik özellikleri

\begin{tabular}{|l|c|c|c|c|c|c|c|c|}
\cline { 2 - 10 } \multicolumn{1}{c|}{} & \multicolumn{2}{c|}{ Duygu Özaslan } & \multicolumn{2}{c|}{ Merve Özkaynak } & \multicolumn{2}{c|}{ Sebile Ölmez } & \multicolumn{2}{c|}{ Toplam } \\
\cline { 2 - 10 } & $\mathbf{n}$ & $\mathbf{\%}$ & $\mathbf{n}$ & $\mathbf{\%}$ & $\mathbf{n}$ & $\mathbf{\%}$ & $\mathbf{n}$ & $\mathbf{\%}$ \\
\hline Etiketleme & 7 & $\% 23,4$ & 14 & $\% 46,6$ & 9 & $\% 30$ & $\mathbf{3 0}$ & $\mathbf{\% 1 0 0}$ \\
\hline Hashtag kullanma & 9 & $\% 26,4$ & 14 & $\% 41,1$ & 11 & $\% 32.3$ & $\mathbf{3 4}$ & $\mathbf{\% 1 0 0}$ \\
\hline Metin kullanma & 10 & $\% 22,3$ & 17 & $\% 37,7$ & 18 & $\% 40$ & $\mathbf{4 5}$ & $\mathbf{\% 1 0 0}$ \\
\hline Emoji kullanma & 10 & $\% 23,2$ & 17 & $\% 39,5$ & 16 & $\% 37,2$ & $\mathbf{4 3}$ & $\mathbf{\% 1 0 0}$ \\
\hline Mention kullanma & 1 & $\% 4,5$ & 10 & $\% 45,5$ & 11 & $\% 50$ & $\mathbf{2 2}$ & $\mathbf{\% 1 0 0}$ \\
\hline Link ekleme & 2 & $\% 33,4$ & 4 & $\% 66,6$ & - & - & $\mathbf{6}$ & $\mathbf{\% 1 0 0}$ \\
\hline Konum bilgisi ekleme & 1 & $\% 100$ & - & - & - & - & $\mathbf{1}$ & $\mathbf{\% 1 0 0}$ \\
\hline
\end{tabular}

Tabloya göre, sosyal medya fenomenlerinin marka işbirliği paylaşımlarında öncelikli olarak metin ekleyerek açıklamalar da bulundukları ve bu metinleri kullandıkları emojilerle destekledikleri görülmektedir. Marka işbirliği paylaşımlarına metin eklemeyen fenomenlerin paylaşım yoğunlukları sırasıyla şöyledir: Sebile Ölmez, Merve Özkaynak, Duygu Özaslan. Paylaşımlarında emojilerden yararlanma yoğunlukları ise, şöyle sıralamak mümkündür: Merve Özkaynak, Sebile Ölmez, Duygu Özaslan. Söz konusu paylaşımlardaki içerik özelliklerine ek olarak tercih edilenler arasında ise, hashtag kullanımı (sırasıyla Merve Özkaynak, Sebile Ölmez, Duygu Özaslan) ve işbirliğinde bulunulan markanın etiketlenmesi (sırasılyla Merve Özkaynak, Sebile Ölmez, Duygu Özaslan) gelmektedir. Ayrıca, markanın paylaşılan görsel içerisine etiketlenmesinin yanı sıra daha düşük oranda paylaşılan görselin altına mention olarak da eklendiği (sırasıyla Sebile Ölmez, Merve Özkaynak, Duygu Özaslan) görülmektedir. Fenomenlerin Instagram hesaplarında yayınladıkları marka işbirliği paylaşımlarında en az tercih ettikleri içerik özellikleri ise, konuyla ilgili detaylı bilgi aktaran link eklenmesi ve konum bilgisinin gönderiye iliştirilmesi olmuştur.

Tablo 5. Fenomenlerin marka işbirliği paylaşımlarında tercih ettikleri paylaşım içerikleri 


\begin{tabular}{|l|c|c|c|c|c|c|c|c|}
\cline { 2 - 10 } \multicolumn{1}{c|}{} & \multicolumn{2}{c|}{ Duygu Özaslan } & \multicolumn{2}{c|}{ Merve Özkaynak } & \multicolumn{2}{c|}{ Sebile Ölmez } & \multicolumn{2}{c|}{ Toplam } \\
\cline { 2 - 10 } \multicolumn{1}{c|}{} & $\mathrm{n}$ & $\%$ & $\mathrm{n}$ & $\%$ & $\mathrm{n}$ & $\%$ & $\mathbf{n}$ & $\mathbf{\%}$ \\
\hline Bilgilendirme & 3 & $\% 23$ & 5 & $\% 38,5$ & 5 & $\% 38,5$ & $\mathbf{1 3}$ & $\mathbf{\% 1 0 0}$ \\
\hline Tanıtma & 3 & $\% 16,6$ & 5 & $\% 27,7$ & 10 & $\% 55,5$ & $\mathbf{1 8}$ & $\mathbf{\% 1 0 0}$ \\
\hline Etkinlik Duyurma & 1 & $\% 20$ & 4 & $\% 80$ & - & - & $\mathbf{5}$ & $\mathbf{\% 1 0 0}$ \\
\hline Satış Çağrıs1 & 3 & $\% 33,3$ & 3 & $\% 33,3$ & 3 & $\% 33,3$ & $\mathbf{9}$ & $\mathbf{\% 1 0 0}$ \\
\hline
\end{tabular}

Tabloya göre, sosyal medya fenomenlerinin marka işbirliği gönderilerindeki paylaşım içerikleri incelendiğinde, öncelikle ürün tanıtımına yönelik paylaşımlarda bulundukları (sırasıyla Sebile Ölmez, Merve Özkaynak, Duygu Özaslan), bunu sırasıyla bilgilendirici içeriklerin, tanıtılan ürünle ilgili satış çağrılarının ve söz konusu marka ile birlikte gerçekleştirilen etkinlik duyurularının takip ettiği görülmektedir.

Tablo 6. Sosyal medya fenomenlerinin paylaşımlarının altına gelen kullanıcı yorumlarının içeriği

\begin{tabular}{|c|c|c|c|c|c|c|c|c|c|}
\hline \multirow{9}{*}{ 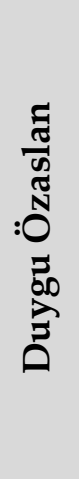 } & \multirow{3}{*}{ Olumlu } & \multicolumn{2}{|c|}{ Fenomen beğenisi } & \multicolumn{2}{|c|}{ Ürün beğenisi } & \multicolumn{2}{|c|}{ Paylaşım beğenisi } & \multicolumn{2}{|c|}{ Toplam } \\
\hline & & $\mathrm{n}$ & $\%$ & $\mathrm{n}$ & $\%$ & $\mathrm{n}$ & $\%$ & $\mathbf{n}$ & $\%$ \\
\hline & & 269 & 98,5 & 2 & $\% 0,7$ & 2 & $\% 0,7$ & 273 & $\% 100$ \\
\hline & \multirow{3}{*}{ Olumsuz } & \multicolumn{2}{|c|}{ Fenomen eleştirisi } & \multicolumn{2}{|c|}{ Ürün eleştirisi } & \multicolumn{2}{|c|}{ Paylaşım eleştirisi } & \multicolumn{2}{|c|}{ Toplam } \\
\hline & & $\mathrm{n}$ & $\%$ & $\mathrm{n}$ & $\%$ & $\mathrm{n}$ & $\%$ & $\mathbf{n}$ & $\%$ \\
\hline & & 70 & $\% 81,3$ & 6 & $\% 6,9$ & 10 & $\% 11,6$ & 86 & $\% 100$ \\
\hline & \multirow{3}{*}{ Nötr } & \multicolumn{2}{|c|}{ Fiyat bilgisi } & \multicolumn{2}{|c|}{ Ürün bilgisi } & \multicolumn{2}{|c|}{ Paylaşım bilgisi } & \multicolumn{2}{|c|}{ Toplam } \\
\hline & & $\mathrm{n}$ & $\%$ & $\mathrm{n}$ & $\%$ & $\mathrm{n}$ & $\%$ & $\mathbf{n}$ & $\%$ \\
\hline & & 1 & $\% 10$ & 9 & $\% 90$ & - & - & 10 & $\% 100$ \\
\hline \multirow{9}{*}{ 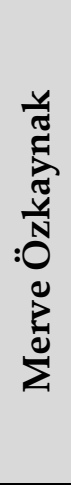 } & \multirow{3}{*}{ Olumlu } & \multicolumn{2}{|c|}{ Fenomen beğenisi } & \multicolumn{2}{|c|}{ Ürün beğenisi } & \multicolumn{2}{|c|}{ Paylaşım beğenisi } & \multicolumn{2}{|c|}{ Toplam } \\
\hline & & $\mathrm{n}$ & $\%$ & $\mathrm{n}$ & $\%$ & $\mathrm{n}$ & $\%$ & $\mathbf{n}$ & $\%$ \\
\hline & & 819 & $\% 93$ & 44 & $\% 5$ & 21 & $\% 2$ & 884 & $\% 100$ \\
\hline & \multirow{3}{*}{ Olumsuz } & \multicolumn{2}{|c|}{ Fenomen eleştirisi } & \multicolumn{2}{|c|}{ Ürün eleştirisi } & \multicolumn{2}{|c|}{ Paylaşım eleştirisi } & \multicolumn{2}{|c|}{ Toplam } \\
\hline & & $\mathrm{n}$ & $\%$ & $\mathrm{n}$ & $\%$ & $\mathrm{n}$ & $\%$ & $\mathbf{n}$ & $\%$ \\
\hline & & 3 & $\% 33,3$ & 3 & $\% 33,3$ & 3 & $\% 33,3$ & 9 & $\% 100$ \\
\hline & \multirow{3}{*}{ Nötr } & \multicolumn{2}{|c|}{ Fiyat bilgisi } & \multicolumn{2}{|c|}{ Ürün bilgisi } & \multicolumn{2}{|c|}{ Paylaşım bilgisi } & \multicolumn{2}{|c|}{ Toplam } \\
\hline & & $\mathrm{n}$ & $\%$ & $\mathrm{n}$ & $\%$ & $\mathrm{n}$ & $\%$ & $\mathbf{n}$ & $\%$ \\
\hline & & 1 & $\% 1$ & 31 & $\% 27$ & 84 & $\% 72$ & 116 & $\% 100$ \\
\hline & & Feno1 & eğgenisi & Ürü & eğenisi & Payla & beğenisi & To & lam \\
\hline & Olumlu & $\mathrm{n}$ & $\%$ & $\mathrm{n}$ & $\%$ & $\mathrm{n}$ & $\%$ & $\mathbf{n}$ & $\%$ \\
\hline$\underline{\Xi}$ & & 525 & 61,1 & 288 & 35,2 & 5 & $\% 0,6$ & 818 & $\% 100$ \\
\hline : & & Fenor & leştirisi & Ürü & leştirisi & Payla & eleştirisi & To & lam \\
\hline$\overline{0}$ & Olumsuz & $\mathrm{n}$ & $\%$ & $\mathrm{n}$ & $\%$ & $\mathrm{n}$ & $\%$ & $\mathbf{n}$ & $\%$ \\
\hline क & & 6 & $\% 37,5$ & 6 & $\% 37,5$ & 4 & $\% 25$ & 16 & $\% 100$ \\
\hline & Nötr & & lgisi & Ür & bilgisi & Pay & a bilgisi & To & lam \\
\hline
\end{tabular}




\begin{tabular}{|c|c|c|c|c|c|c|c|c|c|}
\hline & $\mathrm{n}$ & $\%$ & $\mathrm{n}$ & $\%$ & $\mathrm{n}$ & $\%$ & $\mathbf{n}$ & $\mathbf{\%}$ \\
\cline { 2 - 9 } & $\mathbf{7}$ & $\% 14$ & $\mathbf{2 4}$ & $\% 48$ & 19 & $\% 38$ & $\mathbf{5 0}$ & $\mathbf{\% 1 0 0}$ \\
\hline
\end{tabular}

Tabloya göre, Instagram kullanıcıları tarafından sosyal medya fenomenlerinin kozmetik-kişisel bakım alanında faaliyet gösteren çeşitli markalarla gerçekleştirdikleri işbirliği paylaşımlarının altına gelen yorumların duygu durumlarının sirasıyla olumlu, olumsuz ve nötr olduğunu söylemek mümkündür. Olumlu yorumlar arasında ise, ilk sırada fenomen beğenisi (sırasıyla Merve Özkaynak, Sebile Ölmez, Duygu Özaslan) kategorisi yer almaktadır. Söz konusu yorumlar, paylaşımda bulunan fenomenin kullanıcılar tarafindan ne kadar beğenildiği, takdir edildiği ya da sevildiğini gösteren ifadelerden oluşmaktadır. Bunu, genellikle ürün kalitesi, ürünün alındığının, beğenildiğinin, kullanıldığının bilgisinin paylaşılması gibi yorumları içeren ürün beğenisi kategorisi (sırasıyla Sebile Ölmez, Merve Özkaynak, Duygu Özaslan) takip etmektedir. Paylaşım beğenisi ise, kullanıcı yorumları arasında en az karşılaşılan yorum türü olmuştur. Paylaşım beğenisini içeren yorumlar (sırasıyla Merve Özkaynak, Sebile Ölmez, Duygu Özaslan), paylaşılan fotoğraf ya da videolara dair çekim açısı, kullanılan filtre, arka plan gibi gönderi içeriklerine ilişkin kullanıcı beğenilerini içermektedir. Olumsuz içerikli yorumlar incelendiğinde ise, ilk sırada fenomen eleştirilerini (sırasıyla Duygu Özaslan, Sebile Ölmez, Merve Özkaynak) içeren yorumların geldiği görülmektedir. Bu yorumlar, genel olarak, kullanıcıların fenomene yönelik olumsuz düşüncelerini, fenomeni neden sevmediklerini ya da önerilerine neden güvenmediklerini içeren ifadelerinden oluşmaktadır. Bu yorumları, paylaşımı (sırasıyla Duygu Özaslan, Sebile Ölmez, Merve Özkaynak) ve ürünü (sırasıyla Duygu Özaslan, Sebile Ölmez, Merve Özkaynak) eleştiren yorumlar takip etmektedir. Nötr içerikli kullanıcı yorumlarının yer aldığı kategori yoğunluklarını ise şöyle sıralamak mümkündür: paylaşım bilgisi (sırasıyla Merve Özkaynak, Sebile Ölmez), ürün bilgisi (sırasıyla Merve Özkaynak, Sebile Ölmez, Duygu Özaslan), fiyat bilgisi (sırasılla Sebile Ölmez, Merve Özkaynak, Duygu Özaslan). Buna göre, en fazla nötr kullanıcı yorumunun ürün tanıtımına dair fenomenlerle gerçekleştirilen buluşmalara ya da ürünlere nasıl erişilebileceğine ilişkin kullanıcı sorularını içeren paylaşım bilgisi kategorisi altında toplandığ1 görülmekte, bunu ürüne ve ürünün fiyatına ilişkin sorular takip etmektedir. Dolayısıyla, sosyal medya fenomenlerinin marka işbirliği paylaşımlarının altına gelen olumlu kullanıcı yorumlarının fenomen beğenisi, olumsuz kullanıcı yorumlarının fenomen eleştirisi, nötr kullanıcı yorumlarının ise, paylaşım bilgisi kategorileri altında yoğunluk gösterdiğini söylemek mümkündür. $\mathrm{Bu}$ çerçevede değerlendirildiğinde, kullanıcıların fenomenlerin marka işbirliği paylaşımlarına ilişkin çoğunlukla olumlu yorumlarda bulunduklarını ve kullanıcıların fenomene ilişkin beğenilerinin ya da eleştirilerinin paylaşımı yapılan 
işbirliği ürününe de genellenen yorumlara dönüştüğünü söylemek yanlış olmayacaktır.

\section{Sonuç}

Sosyal medya fenomenleri tarafından paylaşılan içerikler, markalar için önemli reklam mecraları olarak değerlendirilmekte ve günümüzde birçok marka, fenomenin kişisel markasından da yararlanarak, ikili işbirliklerinden oluşan özel ürünler piyasaya sürmektedir. Fenomen ve marka işbirlikleriyle piyasaya sürülerek, Instagram üzerinden tanıtımı yapılan ürün paylaşımlarına odaklanan bu çalışmada $\mathrm{da}$, söz konusu işbirliği ürünlerinin sosyal medya fenomenleri tarafından nasıl duyurulduğunun ve kullanım önerisinin nasıl gerçekleştirildiğinin ortaya koyularak, söz konusu paylaşımların altına gelen kullanıcı yorumlarında öne çıkan temaların ve bu temalara ilişkin duygu durumlarının neler olduğunun belirlenmesi amaçlanmıştır. Bu amaç doğrultusunda, kategorisel içerik analizi tekniğiyle betimsel yönteme dayalı bir alan araştırması gerçekleştirilmiştir. Ulaşılan çalışma sonuçlarına göre, fenomenler, Instagram hesapları üzerinden yayınladıkları işbirliği paylaşımlarında en fazla fotoğraf kullanmakta, bunu video ve sesli video paylaşımları takip etmektedir. Bununla birlikte, fenomenlerin marka işbirliği paylaşımlarının altına metin ekleyerek açıklamalar da bulundukları ve bu metinleri kullandıkları emojilerle destekledikleri, tercih edilen bu öncelikli içerik özelliklerinden sonra ise, sırasıyla, hashtag kullanımının, işbirliğinde bulunulan markanın etiketlenmesinin ve yine markanın paylaşılan görselin altına mention olarak eklenmesinin geldiği görülmektedir. Yayınlanan marka işbirliği paylaşımlarında en az tercih ettikleri içerik özellikler arasında ise, konuyla ilgili detaylı bilgi aktaran link eklenmesi ve konum bilgisinin gönderiye iliştirilmesi yer almaktadır. Buna ek olarak, sosyal medya fenomenlerinin, öncelikli olarak, ürün tanıtımına yönelik paylaşımlarda bulundukları, bunu sırasıyla bilgilendirici içeriklerin, tanıtılan ürünle ilgili satış çağrılarının ve söz konusu marka ile birlikte gerçekleştirilen etkinlik duyurularının takip ettiğini de söylemek mümkündür.

Fenomenlerin Instagram hesapları üzerinden yayınladıkları marka işbirliği paylaşımlarının altına gelen kullanıcı yorumları değerlendirildiğinde, söz konusu yorumlara ilişkin duygu durumlarının sırasıyla olumlu, olumsuz ve nötr olduğu görülmektedir. Bu duygu durumlarını içeren alt kategoriler arasında, olumlu kullanıcı yorumları, fenomen beğenisi; olumsuz kullanıcı yorumları, fenomen eleştirisi; nötr kullanıcı yorumları ise, paylaşım bilgisi kategorileri altında yoğunluk göstermektedir. Diğer yandan, yorumların içeriği incelendiğinde, kullanıcıların fenomen hakkındaki beğeni ya da eleştirilerini, paylaşımı yapılan işbirliği ürününe de genelledikleri görülmektedir. $\mathrm{Bu}$ bakımdan değerlendirildiğinde, markaların kendi ürün ya da hizmetlerinin önerisini yapmaları için seçtikleri "marka mesajının, hedef kitlesine ulaştırılması görevini üstlenen" (Lim vd., 2017, s.20) sosyal medya 
fenomenlerinin, takipçileri nezdindeki olumlu ya da olumsuz imajlarının tanıtımını yaptıkları işbirliği ürününe de aktarıldığını belirtmek olanaklıdır. Bilindiği üzere, fenomen önerisi, fenomenin kendi imajını söz konusu markaya transfer etmesi anlamına gelmektedir. Dolayısıyla, markaların işbirliği gerçekleştirerek, piyasaya çıkardıkları ürünün imajına katkı yapacağını düşündükleri sosyal medya fenomenlerinin seçiminde de, fenomeni takip eden hedef kitlenin özelliği, fenomenin takipçileri nezdindeki imajı, yayınladığı içeriklerin özgünlüğü ve ilgi çekiciliği, takipçilerine sunduğu yaşam stili gibi birçok unsuru göz önünde bulundurmaları büyük önem taşımaktadır. Bu çerçevede ulaşılan araştırma sonuçlarının da, seçilen fenomenin markanın imajına katkı yapacak içeriği üreten bireyler arasından tercih edilmesi gerektiğinin altını bir kez daha çizer nitelikte olduğunu vurgulamak gerekmektedir.

\section{Kaynakça}

Aaker, D. (2014). Markalama. İstanbul: Mediacat Yayınları.

Abidin, C. (2015). "Communicative <3 Intimacies: Influencers and Perceived Interconnectedness". Ada, 8: $1-16$

Abidin, C. (2016). “Visibility Labour: Engaging with Influencers' Fashion Brands and \#OOTD Advertorial Campaigns on Instagram". Media International Australia, 161(1): 86-100.

Araujo, T., Neijens, P. \& Vliegenthart, R. (2017). "Getting the Word out on Twitter: The Role of Influentials, Information Brokers and Strong Ties in Building Word-of-mouth for Brands". International Journal of Advertising, 36(3): 496-503.

Aslan, A. \& Gül-Ünlü, D.G. (2016). “Instagram Fenomenleri ve Reklam İlişkisi: Instagram Fenomenlerinin Gözünden Bir Değerlendirme". Maltepe Üniversitesi İletişim Fakültesi Dergisi, 3(2): 41-65.

Auh, S., Bell, S.J., McLeod, C.S. \& Shih, E. (2007). “Co-production and Customer Loyalty in Financial Services". Journal of Retailing, 83(3): 359-370.

Balık, B. (2017). Celebrity ve Fenomen/Influencer Kullanımı Arasındaki Fark Nedir?. (Çevrimiçi). shorturl.at/rvwEM

Bennet, J. \& Holmes, S. (2010). "The 'Place' of Television in Celebrity Studies". Celebrity Studies, 1(1): 65-80.

Bilgin, N. (2006). Sosyal Bilimlerde İ̧erik Analizi Teknikler ve Örnek Çalı̧̧malar. Ankara: Siyasal Kitapevi.

Boyd, D.M. \& Ellison, N.B. (2007). “Social Network Sites: Definition, History, and Scholarship”. Journal of Computer-Mediated Communciation, 13(1): 210-230.

Casaló, L.V., Flavián, C. \& Ibáñez-Sánchez, S. (2018). “Influencers on Instagram: Antecedents and Consequences of Opinion Leadership". Journal of Business Research, 1-10.

Cha, M., Haddadi, H., Benevenuto, F. \& Gummadi, P.K. (2010). Measuring User Influence in Twitter: The Million Follower Fallacy. Paper presented at the Fourth International AAAI Conference on Weblogs and Social Media, 23-26 May, Washington, USA. 
Choi, S.M. \& Rifon, N.J. (2012). "It is a Match: The Impact of Congruence Between Celebrity Image and Consurmer Ideal Self on Endorsement Effectiveness". Psychology and Marketing, 29(9): 639650 .

Çarkacı, O. (2018). Yeni Kanaat Önderleri: Sosyal Medya Fenomenleri, (Çevrimiçi)., https://bit.ly/2UTCIj6

De Veirman, M., Cauberghe, V. \& Hudders, L. (2017). "Marketing through Instagram Influencers: The Impact of Number of Followers and Product Divergence on Brand Attitude". International Journal of Advertising, 36(5): 798-828.

De Vries, L., Gensler, S. \& Leeflang, P.S.H. (2012). “Popularity of Brand Posts on Brand Fan Pages: An Investigation of the Effects of Social Media Marketing". Journal of Interactive Marketing, 26(2): 83-91.

Djafarova, E. \& Rushworth, C. (2017). "Exploring the Credibility of Online Celebrities' Instagram Profiles in Influencing the Purchase Decisions of Young Female Users". Computers in Human Behavior, 68: 1-7.

Elberse, A. \& Verleun, J. (2012). "The Economic Value of Celebrity Endorsements". Journal of Advertising Research, 52(2): 149-165.

Evans, N.J., Phua, J., Lim, J. \& Jun, H. (2017). “Disclosing Instagram Influencer Advertising: The Effects of Disclosure Language on Advertising Recognition, Attitudes, and Behavioral Intent". Journal of Interactive Advertising, 17(2): 1-12.

Feng, Y. (2016). "Are You Connected? Evaluating Information Cascades in Online Discussion About the \#RaceTogether Campaign". Computers in Human Behavior, 54: 43-53.

Fransen, M.L., Verlegh, P.W.J., Kirmani, A. \& Smith, E.G. (2015). “A Typology of Consumer Strategies for Resisting Advertising, and a Review of Mechanisms for Countering Them". International Journal of Advertising, 34(1): 6-16.

Gamson, J. (2011). "The Unwatched Life is Not Worth Living: The Eveluation of the Ordinary in Celebrity Culture". PMLA, 126(4): 1061-1069.

Glucksman, M. (2017). “The Rise of Social Media Influencer Marketing on Lifestyle Branding: A Case Study of Lucie Fink". Elon Journal of Undergraduate Research in Communications, 8(2): 77-87.

Gormley, A. (2016). "How Brands Can Get More From Their Influencer Relationships". Mumbrella,

Hearn, A. \& Schoenhoff, S. (2016). "From Celebrity to Influencer: Tracing the Diffusion of Celebrity Value Across the Data Stream". (Eds. P.David Marshall \& S. Redmond). A Companion to Celebrity. Chichester: John Wiley \& Sons, p.194-212.

Hwang, Y. (2015). “Does Opinion Leadership Increase the Followers on Twitter". International Journal of Social Science and Humanity, 5(3): 258-264.

Jansen, B.J., Zhang, M., Sobel, K. \& Chowdury, A. (2009). “Twitter Power: Tweets as Electronic Word of Mouth". Journal of the Association for Information Science and Technology, 60(11): 2169-2188.

Kaikati, A.M. \& Kaikati, J.G. (2004). "Stealth Marketing: How to Reach Consumers Surreptitiously". California Management Review, 46(4): 6-22. 
Keller, E. \& Berry, J. (2003). The Influentials: One American in Ten Tells the Other Nine How to Vote, Where to Eat, and What to Buy. New York: The Free Press.

Khamis, S., Lawrence A. \& Raymond W. (2017)."Self-branding,'Micro-celebrity' and the Rise of Social Media Influencers". Celebrity Studies, 8(2): 191-208.

Korotina, A., \& Jargalsaikhan, T. (2016). Attitude towards Instagram Micro-celebrities and Their Influence on Consumers' Purchasing Decisions. Master Thesis in Business Administration. International Business School Jönköping University.

Knoll, J. (2016). "Advertising in Social Media: A Review of Empirical Evidence". International Journal of Advertising, 35(2): 266-300.

Labreque, L.L., Markos, E. \& Milne, G.R. (2011). “Online Personal Branding: Processes, Challenges, and Implications". Journal of Interactive Marketing, 25: 37-50.

Li, R. (2018). "The Secret of Internet Celebrities: A Qualitative Study of Online Opinion Leaders on Weibo". Proceedings of the 51st Hawaii International Conference on System Sciences, p.533-542.

Li, F. \& Du, T.C. (2011). "Who is Talking? An Ontology-Based Opinion Leader Identification Framework for Word-of-mouth Marketing in Online Social Blogs". Desicion Support Systems, 51(1): 190-197.

Li, Y., Ma, S., Zhang, Y. \& Huang, R. (2013). “An Improved Mix Framework for Opinion Leader Identification in Online Learning Communities". Knowledge-Based Systems, 43: 43-51.

Lim, X. J., Cheah, J. H., \& Wong, M. W. (2017). “The Impact of Social Media İnfluencers On Purchase Intention And Them Ediation Effect of Customer Attitude". Asian Journal of Business Research, 7(2), 19-36.

Lyons, B. \& Henderson, K. (2005). “Opinion Leadership in a Computer-Mediated Environment". Journal of Consumer Behavior, 4(5): 319-329.

Marwick, A.E. (2016). "You May Know Me From YouTube: (Micro-) Celebrity in Social Media". (Eds. P.D. Marshall \& S. Redmond). A Companion to Celebrity, Chichester: John Wiley \& Sons, p.333-350.

Marwick, A.E. \& Boyd, D. (2010). “I Tweet Honesty, I Tweet Passionately: Twitter Users, Context Collapse, and the Imagined Audience". New Media \& Society, 13(1): 114-133.

McCracken, G. (1989). "Who is the Celebrity Endorser? Cultural Foundations of the Endorsement Process". Journal of Consumer Research, 16: 310-321.

Nicolau, J. \& Santa-Maria, M. (2013). “Communicating Excellence in Innovation". Economics Letters, 118(1): 87-90.

Ohanian, R. (1990). “Construction and Validation of a Scale to Measure Celebrity Endorsers' Perceived Expertise, Trustworthiness, and Attractiveness". Journal of Advertising, 19(3): 39-52.

Perry, A. \& Wisnom III, D. (2004). Markanın DNA'sl. İstanbul: MediaCat Yayınları.

Randall, G. (2005). Markalaştırma: Stratejilerinizi Planlamada Doğru Rehber, Çev. Elif Özsayar, İstanbul: Rota Yayınları. 
Romeo, D.M., Galuba, W., Asur,S. \& Huberman, B.A. (2011). Influence and Passivity in Social Media. Paper presented at the European Conference on Machine Learning and Principles and Practice of Knowledge Discovery in Databases. 5-9 Semptember, Athens, Greece.

Sabuncuoğlu, A. \& Göker, G. (2014). "Sosyal Medyadaki Yeni Kanaat Önderlerinin Birer Reklam Aracı Olarak Kullanımı: Twitter Fenomenleri Üzerine Bir Araştırma." İletişim Kuram ve Araştırma Dergisi, 38(1): 2-24.

Scott, D. (2011). The New Rules of Marketing and PR: How to Use Social Media, Online Video, Mobile Applications, Blogs, New Releases and Viral Marketing to Reach Buyers Direct. New York: Wiley Publishing.

Senft, T.M. (2008). Camgirls: Celebrity \& Community in The Age of Social Networks. New York: Peter Lang Publishing

Sheth, J.N. (2018). How Social Media Will Impact Marketing Media. (Eds. Heggde, G. \& Shainesh, G.). Social Media Marketing, p. 3-18. Palgrave Macmillan, Singapore.

Spry, A., Pappu, R. \& Cornwell, B.T. (2011). "Celebrity Endorsement, Brand Credibility and Brand Equity". European Journal of Marketing, 45(6): 882-909.

Thomas, G:M. (2004). "Building the Buzz in the Hive Mind". Journal of Consumer Behavior, 4(1): 64-73.

Thoumrungroje, A. (2014). "The Influence of Social Media Intensity and EWOM on Conspicuous Consumption". Procedia - Social and Behavioral Sciences, 148: 7-15.

Turcotte, J., York, C., Irving, J., Scholl, R.M. \& Pingree, R.J. (2015). “New Re-commendations from Social Media Opinion Leaders: Effects on Media Trust and Information Seeking". Journal of computer Mediated Communication, 20(5): 520-535.

Tuten, T.L. \& Solomon, M.R. (2013). Social Media Marketing. London: Sage Publication.

Özgüven-Tayfun, N. (2018). "Fenomen Pazarlama ve Uygulama Örnekleri”. Sosyal, Beşeri ve İdari Bilimlerde Akademik Araştırmalar - 4. (Ed. Fikret Çankaya \& Sabrina Kayıkçı). Ankara: Gece Kitaplığı.

Vargo, S.L. \& Lusch, R.F. (2008). “Service-dominant Logic: Continuing thee Evolution". Journal of the Academy of Marketing Science, 36(1): 1-10.

Watts, D.J. \& Dodds, P.S. (2007). "Influentials, Networks, and Public Opinion Formation". Journal of Consumer Research, 34(4): 441-458.

Weimann, G. (1994). The Influentials: People Who Influence People. New York: State of New York Press.

Woods, S. (2016). Sponsored: The Emergence of Influencer Marketing. University of Tennessee Honors Thesis Projects. (Çevrimiçi). https://bit.ly/2UUjb1N

Yoganarasimhan, H. (2012). "Impact of Social Network Structure on Content Propagation - A Study Using YouTube Data". Quantitative Marketing and Economics, 10(1): 111-150.

Zhao, Y., Kou, G., Peng, Y. \& Chen, Y. (2018). “Understanding Influence Power of Opinion Leaders in E-commerce Networks: An Opinion Dynamics Theory Perspective". Information Science, 426: 131-147.

Zhang, X. \& Dong, D. (2008). "Ways of Identifying the Opinion Leaders in Virtual Communities". International Journal of Business and Management, 3(7): 21-27. 


\section{Ek 1. Sosyal Medya Fenomenlerinin Paylaşımlarının Altına Gelen Kullanıcı Yorumlarında Ön Plana Çıkan Temalara İlişkin Kodlama Formu}

\begin{tabular}{|c|c|}
\hline & 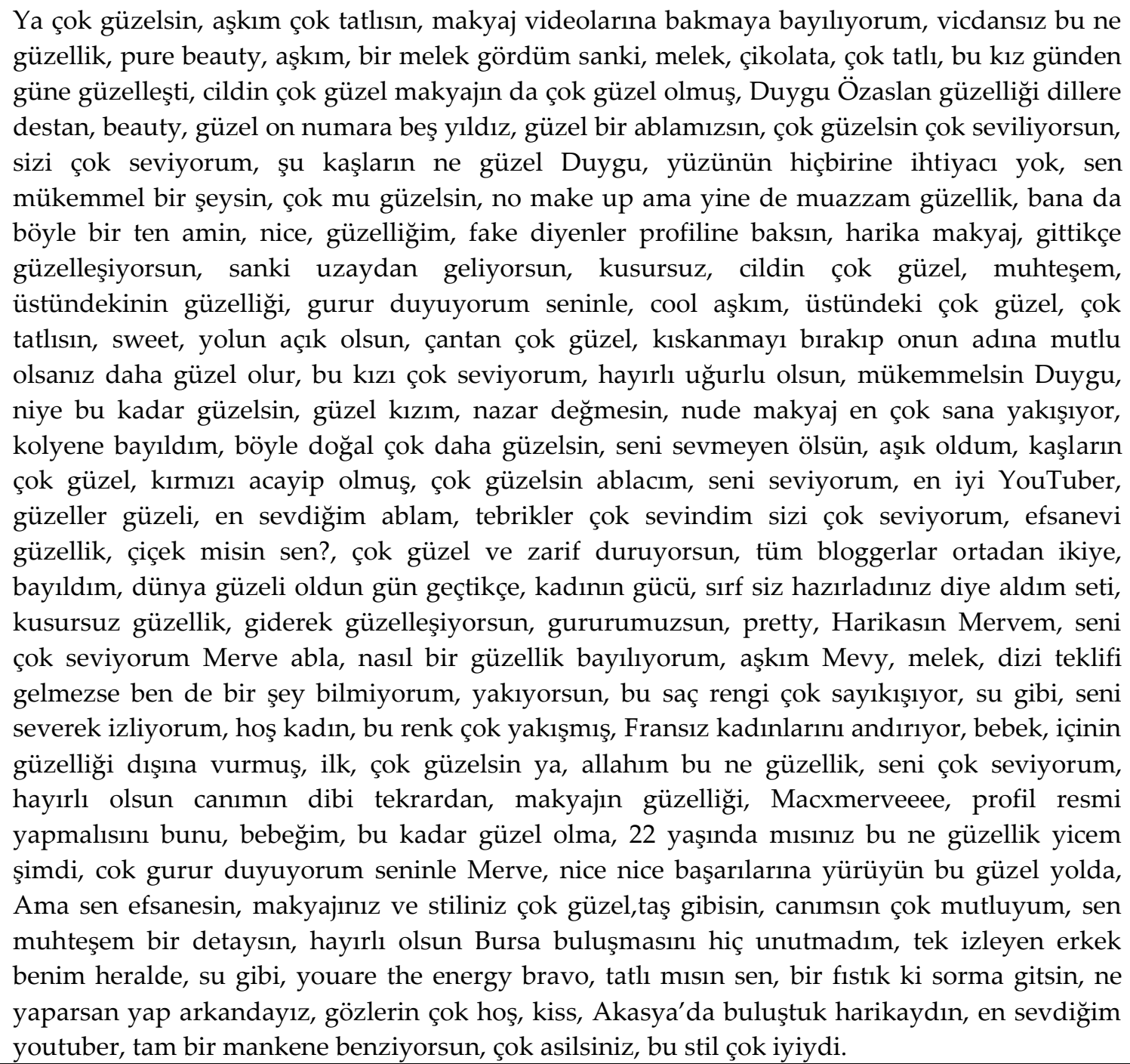 \\
\hline
\end{tabular}




\begin{tabular}{|c|c|}
\hline & $\begin{array}{l}\text { Duygu hanım çok doğal ve çok güzel önerdiğiniz ürünler, renkler muhteşem bayıldım, ürünler } \\
\text { süper, Harmony allığı alacaktım zaten setin zamanlaması harika, almak için sabırsılanıyorum } \\
\text { koşarak gidip alıcam, hemen kaptım bir tane, bir an önce bu ürünlerle makyaj yapmam gerek, } \\
\text { keşke koleksiyonda olmayan ürünleri çıkarsaydın ama olsun hep işbirliği yap biz destekleriz, } \\
\text { Harmony yerine başka bir allık olsaydı da olurdu çok güzel bir set olmuş, gecenin 2'sinde } \\
\text { aldım allığı hiç denemedim ama siz önerdiyseniz süperdir, ruja bayıldım, ruj, far ve allık bende } \\
\text { de var hepsi de süre Mac ürünler, hemen alıcam, tonlar süper, çok güzel olmuş bu set Mac } \\
\text { doğru kişi ile çalışmış, bugün bende aldım ruja bayıldım, muhteşem set, harika ötesi makyaj } \\
\text { ürünleri, makyajınız efsane olmuş, harika bu sefer alacağım bu seti, muhteşem özellikle de ruj, } \\
\text { hemen alıyorum, geçen sene setin sonuncusunu almıştım bu sene beklemeden almak lazım, ay } \\
\text { hemen alınıor, maconline çöktü ilkini kaçırmıştım bu efsane olmuş, ay sonunda alıcam } \\
\text { hemen, hemen satın aldım bir an öne gelsin makyaj yapacağım, ilkini alamamıştım bunu } \\
\text { hemen alacağım, makyaj da set de efsane, alıyor muyuz alıyoruz, keşke bana da hediye olsa, } \\
\text { güzel bir set olmuş harika, güzel bir set hemen aldım onlinedan, ilk mac makyaj malzemlerimi } \\
\text { senin setinle almış oldum pişman olmayacağım bence, Mac is Merve Özkaynak, almamak için } \\
\text { direniyorum ama ne kadar dayanacağım zor, ürün çok iyi gerçekten, pigmentlere ve ürüne } \\
\text { bayıldım o nasıl bir renktir öyle, ruja bayıldım, yerim bu ürünü ben, } 2020 \text { favorisi net, harika } \\
\text { oldu bu ürün, çok güzel bir palet ve makyaj, süper görünüyor, aşık olundu, ben böyle harika } \\
\text { bir şey görmedim, işte bu palet beni bitirir, muhteşem renkler. }\end{array}$ \\
\hline & $\begin{array}{l}\text { Fotoğraflarını hangi uygulamalarla editliyorsun çok hoş vintage bir hava veriyor, hangi } \\
\text { kamerayla bu kadar güzel resim elde edebiliyorsun, ilk haberi verdiğinde çok sevindim son } \\
\text { videonu } 10 \mathrm{kez} \text { izledim, videon çok samimi ve tatlıdı ilk Mac alışverişimi senin sayende } \\
\text { yapacağım, bu çekimler harika olmuş, Mac'in hesabındaki videoyu izledim tam bir } \\
\text { profesyoneldiniz, çok güzel bir haber çok mutlu oldum buna, bu fotoğrafın aynısını } \\
\text { çekmeliyim, bayıldım bu fotoğrafınıza, harika bir resim, şahane ekip şahane işbirliği, harika } \\
\text { ötesi makyaj, ay nasıl meraklandım şimdi hemen bakacağım, videondaki heyecanınla ben de } \\
\text { heyecanlandım, pcde de video açık şu anda, bu fotoğraf ayrıca güzel olmuş, izledikten sonra } \\
\text { tekrar yazıyorum mükemmel, çekimler } 10 \text { numara olmuş. }\end{array}$ \\
\hline & $\begin{array}{l}\text { Buradaki örneğimizde makyaj malzemelerinin değil, bir yüzün güzelliğinin daha önemli } \\
\text { olduğunu görüyoruz, bu yaşa bu kadar dolgu, bu ne ya, gerçekten çok yapmacıksın, bakın ne } \\
\text { kadar güzelim, bu fotoğraftan nasıl böyle bir şey uydurdun merak ediyorum, yeni saçın olmadı } \\
\text { Duygu ya } 13 \text { yaşında gibi görünüyorsun, sil şunu, makyaj yapıyorsun hep aynısın, surat ifaden } \\
\text { çok değişmiş bence artık ne yaptırdığını söyle bir göz altıyla olacak iş değil bu, saçma sapan } \\
\text { şeylerle gündeme gelme peşindesin, rüküşlügün, bu kız kime özeniyor ya, egoya bak, } \\
\text { gerçekten böyle mi geziyorsun, tamam anladık markan çıktı ya, o nasıl bir kombin ya, } \\
\text { kombinin berbat, senin de haberin yoktu tabi koleksiyon olduğundan ondan bu saçma ifaden, } \\
\text { abartmadın mı artık yeter ya, ne bu havalar, görgüsüzce olmuş, max } 3 \text { metallica şarkısı } \\
\text { biliyorsundur, yine o uzaylı ayakkabılarını giymiş, çantanı çekmek için bu kadar çaba, sayko } \\
\text { gibi yürümek, ama güzel kız atarı var, son videodaki makyajın berbat, hiç beğenmedim, ben de } \\
\text { diyorum maskara ruj aydınlatıcı neden bu kadar kalitesiz, uyuz Duygu, hiçbir özgün güzelliğin } \\
\text { yok çabalama tırmalama, bu kızı tanımıyorum ama hiçbir özü yok, bu ne biçim bakış olmuş, o } \\
\text { kadar çok şey sürüyorsun ki cilt kanseri olmandan korkuyorum, estetik çok kötü olmuş, önüne } \\
\text { gelen marka çıarıyor. }\end{array}$ \\
\hline
\end{tabular}




\begin{tabular}{|c|c|}
\hline 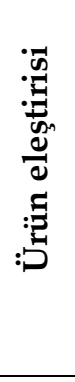 & $\begin{array}{l}\text { Abla paramız yok olsa alacağız inan olsa iki seti de alırız, alamadan bitiyor, ürünler online'da } \\
\text { yok ama, senin o sete vereceğim parayla gratis indiriminden neler alırım neler, maskara iyi } \\
\text { durmuyor, sen mükemmelsin ama ürünler değil, } 2 \text { yıl öncesine kadar marka çantan yoktu } \\
\text { şimdi her dakika 10-15 bin tllik çanta alıyorsun inandırıcı ol biraz, 300tı'lik maskarayı sattın mı, } \\
\text { Harmony allık bana biraz donuk geldi daha canlı olsaydı iyi olurdu, pakette geçen seneki gibi } \\
\text { maskara da olsaydı keşke, lütfen mac'in internet sitesini düzeltmelerini öner gerçekten alıveriş } \\
\text { yapamıyoruz, berbat ürün, Watsons mağazasında bulamadım asla bilgileri yok, pigmentleri iyi } \\
\text { değil, fiyat çoksa almayın bence daha iyileri var. }\end{array}$ \\
\hline 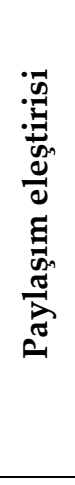 & $\begin{array}{l}\text { Üzülme duygu, ilk defa ağzın kapalı, kirpikler çok sönük kalmış bence, almayacağız uzatma, } \\
\text { sınırlı sayıdadır beklentinin altında satış olduğunda satmak için en güzel taktiktir, sat sat } \\
\text { bitmedi bu rujlar ya, hiçbir özelliği olmayan albeni yoksunu bir kız daha olağan dışı biriyle } \\
\text { çalışabilirdin, bobbi brown'un yapabileceği en saçma ve gereksiz işti sanırım, ne bu şimdi çok } \\
\text { saçma, kimsenin Duygu'yu takmayışı, kim bu şarlatan, cool olmak için böyle giyinirim, bu } \\
\text { video ysl çantam var videosudur, James ağlıyor, videonu niye story'de paylaşmıorsun, sana } \\
\text { bayılıyorum ama son videondaki makyaj nedir öyle, şu dudağını büyüte büyüte tamamen bir } \\
\text { dudağa dönüşeceksin, İstanbul'da olmayanlar ne yapacak?, bu ürünü videoda göstermedin, } \\
\text { çok shop anneciğim, görüntü çok mat olmuş, kendi paletinizle ilgili daha çok video } \\
\text { paylaşmanız gerek, Swatchlarını da paylaşmanız gerek. }\end{array}$ \\
\hline 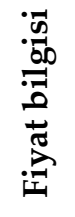 & Fiyatı çok mu?, Mac online'da 195tl ye düşüyor sepette haberiniz olsun, fiyat?, fiyat ne kadar. \\
\hline 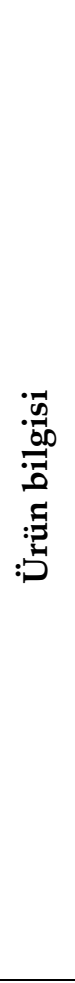 & $\begin{array}{l}\text { Rujun ne ve kodu ne?, rujun ne?, rujun üzerinde gloss mu var yoksa duruşu nemli mi?, rujun } \\
\text { kalıcı mı fotoğrafta pek öyle durmuyor, rujun numarası adı nedir?, videosunu ne zaman } \\
\text { yayınlayacaksın?, kapatıcının hangi rengini kullanıyorsun?, canım son videoda kullandığın } \\
\text { rujun ismi ve numarası ne söylersen sevinirim, bu dudak dolgunlaştırıcı ürünleri nasıl } \\
\text { kullanıyorsun?, hemen aldım ürünler süper, senin profesyonel seçimlerinin Mac ile buluşması } \\
\text { çok isabetli olmuş bu ürünler, Mervecim çok başarılı bir işbirliği olmuş üründe stok veya satış } \\
\text { süresinde kota var mı?, ben de aldım bu ürünler çok başarılı, Merve abla yüzümdeki sivilce ve } \\
\text { pütürcükler için sence işe yarar mı yoksa daha da yayılır mı?, Felaket güzel ve büyük indirimli } \\
\text { Duygu Özaslan'ı alacağına bunu al bence, Mac Harmony allığı iki senedir kullanıyorum tek } \\
\text { vazgeçemeceğim ürün, her makyajla uyumlu, yüzündeki makyajı bu ürünlerle mi yaptın?, Ben } \\
\text { bugün Zonguldak'taki Mac'e sordum lansmanı yapılmadı henüz dedi, bu sete uygun pudra } \\
\text { öneriniz var mı?, siparişimi teslim aldım çok güzel bir set olmuş, güneş lekelerinden } \\
\text { kurtulmada işe yarar mı?, rujunuz çok güzel setteki mi?, makyajınızada hengi malzeleri } \\
\text { kullandınız?, Mac x sizin çıkardığınız marka mı?, ruj hariç ikisi neden var ki elimde?, ceketin } \\
\text { nereden acaba çok güzel. Yeni seti almaya çalışıyorum kampanya kodu var mı? Ben yurt } \\
\text { dışında kalıyorum ürünü nasıl alabilirim, yarın ilk iş Cabacity Mac'e gidicem orda bulabilir } \\
\text { miyim? Rujun burdaki rengi ile videodaki rengi arasında fark var hangisi gerçek rengi acaba?, } \\
\text { Avrupa'daki Maclerde yok dimi? Geçen seneki mac setiniz yine çıksa, İzmir'deki Mac } \\
\text { mağazalardan bulabilir miyiz şu an koşarak gidicem, kendi fırçalarınla mı kullandın?, doğal ve } \\
\text { parıltısız bir makyaj için hangi paleti tercih etmeliyiz?, bu palet geçici koleksiyon mu?, burada } \\
\text { hangi fondöteni kullanıyorsun?, bu ürünlerle sadece göz makyajı mı yapıllyor?. }\end{array}$ \\
\hline
\end{tabular}


O 55 Mac mağazasını nasıl öğrenebilirim?, bu fotoğrafında yüzündeki makyaj malzemeleri Mac markasından mı?, Merve 1 Haziran'da kaçta burada olacaksın?, Mervecim Pazartesi satışta olacak doğru anladım değil mi?, keşke yurtdışında da olsa bu ürünlerin satışı ne zamana kadar geçerli, Bursa'daki buluşma saat kaçta?, Abla Bursa Korupark'a kaçta geliyorsun?, sadece - Türkiye'de mi satışı var?, yaptığın işleri çok beğeniyorum markayla işbirliği yapmak senin için

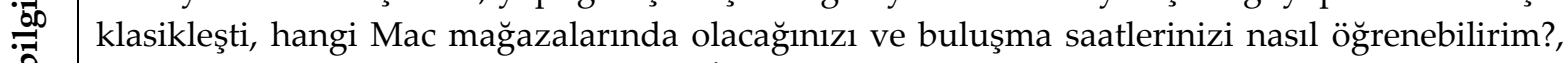
: Temmuz'da buluma yapacak mısınız?, İzmir'e ne zaman geleceksiniz?, Tatile gidecek çocuklu aileler için ilk yanımıza almamız gerekenler listesine eklenebilir mi?, gelmek isterdim maalesef çok uzak, her seferinde kaçırıyorum ama bu sefer denk geleceğim, Ankara'ya ne zaman geleceksiniz?, İzmir Park'a gelin lütfen, İlla seti almamız gerekiyor mu gelebilmek için?, Kayseri'ye gelecek misiniz?, ben gelemeyeceğim ama Mall of İstanbul'da yapın lütfen, Kocaeli'de dört gözle seni bekliyoruz, bunun dişında İstanbul'da bir buluşma daha olacak mı?, seti daha önceden alanlar da gelebilir mi?, buluşma saatlerini neden uzatmıyorsunuz?, karşı tarafta olamaz miydı?, Londra'da satılıyor mu?, Almanya'dan nasil alabilirim?, Avrupa dağıtımı oldu mu?, Yurtdışında nereden bulabilirim?. 